\title{
PERAN LANSIA DALAM PELESTARIAN BUDAYA
}

\author{
Suharti ${ }^{1}$, Siti Partini ${ }^{2}$, dan Suwarjo ${ }^{2}$ \\ ${ }^{1}$ Fakultas Bahasa dan Seni Universitas Negeri Yogyakarta \\ ${ }^{2}$ Fakultas Ilmu Pendidikan Universitas Negeri Yogyakarta \\ Email: hartifbs@yahoo.com
}

\begin{abstract}
Abstrak: Peran Lansia dalam Pelestarian Budaya. Penelitian ini bertujuan untuk mendeskripsikan peran lansia dalam pelestarian budaya di Daerah Istimewa Yogyakarta. Penelitian ini menggunakan penelitian kualitatif dengan sumber data para lansia di Daerah Istimewa Yogyakarta. pengumpulan data dengan wawancara mendalam dan observasi berpartisipasi. Data dianalisis secara induktif dengan kategorisasi dan perbandingan berkelanjutan. Hasil penelitian menunjukkan bahwa peran lansia dalam pelestarian budaya Jawa adalah sebagai 1) teladan atau guru dari berbagai sisi kehidupan berkarya, berkomunikasi, bertingkah laku, dan berbusana; 2) pengarah, penasehat, dan pengendali dalam kehidupan kesehariannya yang meliputi lingkungan keluarga, lingkungan masyarakat, dan lingkungan pekerjaan atau profesi bagi yang masih aktif bekerja; 3) penyemangat, secara aktif dapat memberikan semangat kepada yang lebih muda dalam lingkungan keluarga, tempat tinggal dan tempat kerjanya; 4) sahabat, teman di lingkungan keluarga, tempat tinggal maupun di tempat bekerja.
\end{abstract}

Kata kunci: lansia, pelestarian budaya, peran

\begin{abstract}
The Role of the Elderly in Cultural Preservation. This study was aimed at describing the role of the elderly in the cultural preservation in Yogyakarta. This study used a qualitative research with data sources of the elderly in Yogyakarta. The data were collected through in-depth interviews and participating observation. Then the data were analyzed inductively with categorization and continuous comparison. The results shows that the roles of the elderly in the preservation of Javanese culture are as 1) exemplary or teachers from different sides of life at work, communicate, behave and dress; 2) steering, advisory, and control in their daily lives that include family, community, and environment for the job or profession that is still active; 3) encouragement, can actively encourage the younger ones in the family environment, residence and place of work; and 4) friend, a friend in the family, home or at work.
\end{abstract}

Keywords: culture preservation, elderly, role

\section{PENDAHULUAN}

Era globalisasi membawa tantangan sekaligus peluang bagi semua bangsa dan semua orang. Kemajuan-kemajuan yang terjadi sebagai dampak dari globalisasi tersebut, dapat merupakan suatu peluang untuk memajukan budaya lokal dan dapat pula sebagai ancaman bagi suatu kelestarian budaya budaya lokal suatu bangsa. Oleh karena itu usaha-usaha yang bertujuan untuk melestarikan suatu budaya perlu dilakukan.

Berbicara hal pelestarian budaya tidak dapat dipisahkan dengan keberada- 
an lansia, yang merupakan kepanjangan tangan nenek moyang dalam pewarisan budaya. Nenek moyang kita melalui para lanjut usia mewariskan budaya luhur yang terkandung dalam berbagai naskah kuno dan kehidupan sehari-hari merupakan kearifan lokal untuk menyikapi kemajuan zaman, yang mampu membentengi bangsa ini dari distorsi modernitas. Hal ini sejalan dengan hasil Swasono (1995), yang menyatakan bahwa para lanjut usia merupakan pemelihara kelestarian adat dan budaya.

Pada dekade belakangan ini jumlah penduduk lanjut usia semakin meningkat. Meningkatnya jumlah penduduk lansia ini merupakan dampak positif keberhasilan pembangunan di bidang kesehatan, keluarga berencana, dan sosial ekonomi sehingga menurunkan angka kematian bayi, ibu, dan nagka vertilitas serta menghasilkan perbaikan gisi masyarakat yang bermuara pada peningkatan angka harapan hidup. Peningkatan tersebut bila tidak disikapi dengan bijaksana akan menimbulkan masalah bahkan ancaman, baik bagi lansia itu sendiri, keluarga, maupun bangsa. Selain itu kondisi lansia yang semakin menurun potensial untuk menimbulkan masalah. Hal itu disebabkan tingkat ketergantungan generasi lansia lebih tinggi dibandingkan dengan ketergantungan pada usia dewasa yang lain.

Berdasarkan alasan-alasan di atas, selain para lansia memiliki andil yang besar pada pewarisan budaya, para lansia juga memiliki keterbatasan yang harus mendapatkan penanganan yang bijaksana agar bermanfaat bagi semuanya, baik bagi lansia itu sendiri maupun pada generasi penerusnya Oleh karena itulah penelitian mengenai peran lansia dalam pelestarian budaya perlu dilakukan, agar dapat memberikan manfaat bagi kaum lansia sendiri maupun kepada anak-cucu, keluarga, masyarakat, bangsa dan negara. Berdasar latar belakang masalah tersebut perlu dilakukan penelitian tentang bagaimanakah perran para lansia dalam pelestarian budaya dan upaya-upaya apa sajakah yang dilakukan para lansia dalam melestarikan budaya tersebut.

Jumlah penduduk Indonesia yang mencapai lanjut usia (60 tahun ke atas) dari tahun ke tahun semakin meningkat, seiring dengan meningkatnya angka harapan hidup rata-rata penduduk Tahun 1999 Indonesia telah memasuki masa penduduk berstruktur tua karena 15,4 juta jiwa $(7,4 \%$ dari keseluruhan penduduk) berusia 60 tahun atau lebih. Bahkan di Propinsi Daerah Istimewa Yogyakarta, pada tahun 1995, persentase penduduk usia lanjut telah mencapai $12,5 \%$ dari populasi penduduk di DIY, sehingga Propinsi DIY disebut sebagai Ageing Population.

Kondisi tersebut antara lain disebabkan oleh keberhasilan pembangunan baik dibidang kesehatan, keluarga berencana maupun bidang sosial ekonomi lainnya sehingga menurunkan angka kematian bayi, ibu dan angka fertilitas serta menghasilkan perbaikan gizi masyarakat yang ber-muara pada peningkatan angka harapan hidup. Dengan meningkatnya angka harapan hidup berarti pula meningkatnya jumlah lansia. Meningkatnya jumlah lansia tersebut perlu memperoleh perhatian yang serius terutama untuk mengusahakan bagaimana agar kelompok lansia tetap menjadi aset produktif, tidak sebaliknya menjadi beban yang harus ditanggung oleh generasi muda. Lebih-lebih dalam situasi krisis seperti saat ini, meningkatkan peran lansia dalam segala bidang merupakan hal yang sangat signifikan. Lansia diharapkan menjadi sumber daya 
yang potensial dalam keikutsertaannya membangun bangsa.

Lansia sebagai sarana pewarisan budaya merupakan pelaku yang sangat strategis. Budaya sebagai hasil pemikiran masyarakat untuk mencukupi kebutuhan peningkatan hidupnya terwujud dalam budaya fisik, budaya perilaku, dan nilainilai budaya. Nilai budaya merupakan suatu rangkaian dari konsepsi-konsepsi abstrak yang hidup dalam pikiran sebagian besar dari warga masyarakat, mengenai apa yang dianggap penting dan berharga, tetapi juga mengenai apa yang dianggap remeh dan tidak berharga dalam hidup (Koentjaraningrat, 1990). Wujud budaya tersebut tercermin dalam tujuh unsur-unsur kebudayaan (Cultural Universals), yakni: (1) sistem peralatan dan perlengkapan hidup (sistem teknologi), (2) sistem mata pencaharian, (3) sistem kemasyarakatan, (4) bahasa, (5) kesenian, (6) sistem pengetahuan, dan (7) sistem religi.

Setiap unsur memiliki sistem yang sesuai dengan budaya setempat. Namun, bila budaya tidak dilestarikan, lama kelamaan akan menipis, mungkin menghilang tergerus oleh kemajuan ilmu dan teknologi yang berkembang sangat pesat dalam era globalisasi. Pada era globalisasi budaya setempat atau budaya lokal yang kurang kokoh pemilikannya oleh pendukung budayanya, akan menyebabkan mudahnya budaya lokal tersebut terseret atau terlindih oleh globalisasi tersebut karena ketiadaan patokan atau akar yang kuat yang bersumber pada budaya lokalnya.

Globalisasi, membawa dampak positif maupun negatif. Dampak positif antara lain mendukung pesatnya komunikasi dan transportasi antartempat yang berjauhan, sehingga dunia seolaholah menjadi sempit. Apa yang terjadi di X langsung sudah dapat tersebar ke pelosok dunia dengan sekejap. Dampak negatifnya dapat disebutkan, munculnya pengaruh-pengaruh yang kurang sesuai dengan budaya dan tatanan hidup suatu bangsa. Pengaruh antarbudaya memang tidak bisa dihindari, namun demikian dibutuhkan suatu filter untuk menyaring pengaruh-pengaruh negatif yang berasal dari budaya lain.

Para lanjut usia merupakan sosok yang arif dan bijaksana. Mereka memiliki pengetahuan, sikap dan tingkah laku yang diperlukan untuk menyaring budaya yang kurang sesuai dengan kondisi masyarakat setempat. Berdasarkan pe-ngalamannya mereka telah berhasil menyaring pengaruh-pengaruh budaya luar baik segi positif maupun negatifnya, yang dapat dikatakan sebagai pelestari budaya. Para lansia menjaga, membangun, dan menyebarkan ke lingkungkungan sekitarnya dan mewariskan kepada anak cucunya. Pengalaman lansia ini dikuatkan oleh hasil penelitian yang dilakukan oleh Swasono (1995), bahwa para lanjut usia merupakan pemelihara kelestarian adat dan budaya. Berdasarkan hasil penelitian tersebut, diharapkan para lansia saat ini masih dapat berperan dalam melestarikan dan mensosialisasikan kepada generasi yang lebih muda.

\section{METODE}

Penelitian ini menggunakan pendekatan kualitatif naturalistik, yaitu penelitian yang yang dilakukan pada latar alamiah yang bersifat jamak, dibentuk, dan holistik (Williams, 1988), bersifat menyeluruh, yang meletakkan berbagai unsur dari pokok penelitian dalam suatu jalinan keterkaitan yang dideskripsikan atau hendak diperdalam pemahamannya (Sedyawati, 2002). Penggunaan pendekatan tersebut di- 
karenakan penelitian ini akan melihat gejala penelitian secara apa adanya tanpa merubah situasi, dan mencoba melihatnya secara holistik.

Penelitian ini dilakukan di Daerah Istimewa Yogyakarta, dengan setting penelitian menyeluruh terdiri dari daerah pedesaan dan kota, yang dimungkinkan terdapat perbedaan pada pola pelestarian budaya antara penduduk yang hidup di pedesaan dan di perkotaan. Kenyataan sekarang, perbedaan desa dan kota sudah tidak begitu kelihatan. Perbedaan desa-kota yang tipis tersebut dapat dialami setelah adanya listrik masuk desa, dan selanjutnya diikuti oleh banyaknya perumahan-perumahan yang menjamur mengarah ke luar kota.

Sumber data dalam penelitian adalah para lanjut usia sebagai generasi yang mempunyai peran sebagai pelestari budaya, sehingga merupakan informan yang sesuai untuk mengungkap gejala penelitian ini. Yang dimaksud dengan lanjut usia adalah mereka yang berusia 60 tahun ke atas (UU Nomor 13 Tahun 1998). Penentuan subyek atau informan dilakukan secara purposif dengan melihat ciri-ciri tertentu pada subyek. Adapun ciri yang ditentukan adalah (1) Pria/wanita, (2) lansia dalam kondisi sehat, dan (3) mampu menjadi informan penelitian. Penentuan informan di-lakukan melalui key informan secara acak dari warga yang mengetahui secara jelas kondisi lansia setempat, kemudian bergulir pada lansia yang sesuai dengan karakteristik sumber data yang diinginkan.

Penelitian ini dengan menggunakan metode kualitatif, data penelitian dikumpulkan dengan metode observasi dan wawancara mendalam Instrumen Penelitian adalah peneliti sendiri dengan panduan observasi dan panduan wawancara yang disusun berdasarkan konsep teori tentang peran lansia dalam pelestarian budaya yang menjadi bingkai dalam penelitian ini. Keabsahan data untuk mendapatkan derajat kepercayaan dilakukan dengan ketekunan pengamatan; triangulasi metode dan sumber; member check; dan peer debrifing.

Ketekunan pengamatan dilakukan sewaktu peneliti mengadakan wawancara mendalam sekaligus peneliti mengadakan pengamatan berperanserta tentang perilaku lansia dalam menyikapi ataupun dalam memberikan jawaban-jawaban pertanyaan dari peneliti, maupun perilaku lansia dalam kesehariannya.

Data yang di dapatkan dianalisis secara kualitatif dengan anayisis model interactif (Milles \& Huberman, 1994) dan analisis tematik dari Spradley (1997).

\section{HASIL DAN PEMBAHASAN}

Temuan penelitian tentang peran lansia dalam pelestarian budaya didasarkan data yang dianalisi.dan selama pengambilan data dan setelah data terkumpul. Sebelum dikemukakan temuan penelitian perlu dijelaskan hal-hal yang menjembatani dibicarakannya temuan penelitian, yakni situasi kehidupan lansia di lingkungan sehari-harinya.

Para lansia yang menjadi sumber data dalam penelitian "Peran Lansia dalam Pelestarian Budaya" menjalani kehidupannya dalam lingkungan kompleks perumahan dinas - umum, di perkampungan umum, di Daerah Istimewa Yogyakarta. Para lansia hidup di dalam keluarga tinggal dalam satu rumah yang terdiri dari bapak-ibu; bapak, ibu dan anak; dan bapak, ibu, anak, menantu ditambah cucu. Dalam kesehariannya para lansia menjalani kehidupannya dengan tetap aktif se-bagai seorang pengajar, pensiunan PNS/swasta, pedagang, aktif dalam kehidupan bermasyarakat, mengaji, 
dan mengurus keluarga, dan lansia karena .usia berkisar 80 tahun lebih, sudah tidak kuat bekerja dan walaupun sedikit masih memiliki penghasilan sendiri dari hasil pertanian.

Kehidupan kesehariannya, keluarga lansia hidup dengan seorang atau lebih anak, ada yang mempunyai pembantu rumah tangga dan tidak memiliki pembantu rumah tangga. Dengan demikian situasi kehidupannya tentu bervariasi. Kehidupan yang dijalaninya - suami isteri bekerja dari awal mula berkeluarga dengan anak-anak yang masih kecil, harus membagi waktu dengan baik antara mengawasi anak, membimbing belajar, menyediakan makan keluarga, dan bekerja, serta kegiatan lainnya. Dan pada gilirannya sang anak telah berkeluarga orang tua yang telah menginjak usia lansia kegiatannya pun bertambah yakni menimang cucu, mengantar cucu ke sekolah, membimbing belajar dan menemani bermain.

Kehidupan lansia di Daerah Istimewa Yogyakarta berdasarkan tempat tinggalnya dapat dikelompokkan menjadi lima kelompok yakni (1) ibu lansia, anak lansia, menantu, dan cucu, (2) suami isteri lansia, anak, tambah pembantu, (3) suami isteri lansia, anak, (4) suami isteri lansia, anak - menantu, cucu, tambah pembantu, dan (5) suami isteri lansia. Berdasarkan profesinya keluarga lansia dapat dikelompokkan ke dalam yakni (1) suami isteri PNS, (2) suami PNS isteri dosen/guru, (3) suami dosen isteri ibu rumah tangga, (4) suami dosen isteri wirausaha, (5) suami wiraswasta isteri dosen/guru, dan (6) lansia pedagang/ petani Dilihat dari tempat tinggal dan profesi ini peran lansia dalam pelestarian budaya dan upaya-upaya yang dilakukan dalam pelestarian budayanya menjadi variatif.
Pelestarian budaya dalam kehidupan sehari-hari yang dilakukan lansia dapat melalui hubungan antar anggota keluarga, hubungan bertetangga kanan kiri, lewat pertemuan-pertemuan warga, dan lewat profesinya sebagai guru/ dosen, wiraswasta, dan ibu rumah tangga. Boleh dikatakan di setiap kesempatan para lansia menjalankan perannya sebagai pewaris kebudayaan terutama diutamakan dalam pembentukan manusia yang berbudaya yang memiliki sopan santun, dapat membedakan baik dan buruk, dapat menerapkan keadilan, dan bertanggungjawab, yang dapat dikatakan sebagai manusia yang berbudi luhur.

Setelah pembicaraan situasi kehidupan lansia dalam menjalani kehidupan kesehariannya dapat dikemukakan temuan penelitian berkaitan dengan peran lansia dalam pelestarian budayanya. Budaya yang dimaksud adalah budaya Jawa karena di wilayah DIY budaya yang ada adalah budaya Jawa.

Pelestarian budaya di sini dibatasi pada nilai-nilai budaya yang berkaitan dengan kejujuran, tanggung jawab, kebaikan, dan unggah-ungguh sebagai bagian tak terpisahkan dalam usaha pembentukan budi luhur. Pembinaan budi luhur ini terkait dengan ungkapan tradisional "ajining dhiri saka lathi, ajining awak saka tumindak, ajining raga saka busana". Ungkapan tradisional ini dapat dimaknai bahwa dalam kehidupan bermasyarakat seseorang dapat dihargai oleh orang lain apabila mereka dapat menjaga tutur katanya, dapat menjaga tingkah laku, dan menerapkan busana sesuai dengan kehidupan bermasyarakat, baik masyarakat profesi maupun sosialnya.

Ajining dhiri saka lathi ungkapan yang dapat dimaknai bahwa manusia hidup di masyarakat dapat dihargai, 
dihormati oleh orang lain apabila manusia tersebut dapat menjaga tutur kata, yakni orang hidup harus dapat mengendalikan tutur katanya sesuai dengan situasi. Konteksnya Ajining awak saka tumindak, orang akan dihormati bila manusia dapat berperilaku sesuai dengan aturan yang berlaku di lingkungannya. Ajining raga saka busana adalah manusia dihormati oleh sesamanya apabila seseorang dalam kehidupannya berbusana sesuai dengan diri pribadi serta dapat menyesuaikan dengan konteksnya.

Ketiga ungkapan tersebut tidak dapat dipisah-pisah tetapi merupakan satu kesatuan. Ketiganya saling melengkapi tidak berdiri sendiri-sendiri, keberadaannya saling membutuhkan. Orang dapat bertutur baik tetapi kurang memperhatikan perilakunya ataupun kurang memperhatikan busana yang dikenakannya akan menyebabkan adanya ketimpangan.

Pengetahuan, keterampilan menerapkan ungkapan tersebut dalam kehidupan sehari-hari tidak mudah. Dan inilah salah satu peran para lansia untuk mewariskan atau menularkan kepada anak cucu serta generasi penerusnya yang berada di lingkungannya, baik lingkungan tempat tinggal, lingkungan pekerjaan, maupun lingkungan kegiatan sosialnya. Peran lansia kaitannya dengan pewarisan budaya dalam pembentukan generasi penerus yang berbudi luhur ini lewat penerapan ajining dhiri saka lathi, ajining awak saka tumindak, dan ajining raga saka busana dapat ditemukan berbagai peran seperti berikut.

Di dalam kehidupan seharihari orang tidak dapat dipisahkan dengan kosa kata teladan ataupun guru. Dalam budaya Jawa tingkah laku sesorang di dalam pergaulan di dalam keluarga, masyarakat pada umumnya selalu dikaitkan dengan kosa kata teladan ataupun guru. Begitupun kehidupan lansia di dalam kehidupan sehariharinya selalu harus mengingat kosa kata teladan ataupun guru.

Teladan di sini adalah kehidupan lansia baik tutur kata, perilaku dan berbusananya harus dapat dijadikan suri tauladan bagi anak cucunya ataupun bagi generasi mudanya. Kosa kata teladan dapat disamakan dengan guru, sebagai lansia segala perilakunya harus dapat dijadikan teladan atau panutan bagi anak cucu ataupun warga sekitarnya. Segala tutur katanya, perilaku dapat digugu lan ditiru oleh generasi penerusnya, baik anak cucu hubungan darah ataupun oleh anak cucu dalam artian yang luas, yakni anak cucu sebagai penerus bangsa. Peran lansia sebagai teladan atau guru ini didukung pernyataan Ibu Hami seperti berikut.

"...menawi kita kepengin dipun aosi dening para anem, sedaya tindaktanduk, muna-muni sedaya kedah dipuntata, boten saged sasekecanipun piyambak. Awit sedaya wau kedah saged dados panutan dhateng putra wayah. Awakipun piyambak kedah saged dados panutan ingkang sae, sampun ngantos dados panutan awon...."

“...kalau kita ingin dihormati oleh orang muda, semua perilaku, tutur kata kita harus ditata, tidak bias bericara, bertindak sekehendak hati. Karena semua perbuatan, tutur kata tersebut harus dapat digunakan sebagai suri tauladan oleh anak cucu kita. Kita tidak dapat digunakan sebagai teladan yang kurang baik". 
Pernyataan Ibu Hami tersebut terlihat dalam perilaku kesehariannya dalam bertutur kata, bersikap kepada teman sesamanya, dan juga kepada siapapun selalu menghormati mitra bicaranya, tanpa memandang statusnya. Sikap ini juga dapat dilihat pada sikap salah seorang putranya yang bersikap ramah kepada tamu-tamu orang tuanya. Walaupun putra ibu itu telah memiliki pendidikan lebih dari orang tuanya juga kedudukan yang lebih baik tetapi sang putra tersebut tetap bersikap dan menempatkan diri sebagai anak. Pemandangan yang harmonis dari sebuah keluarga tersebut didukung pernyataan Ibu Hami seperti berikut.

“...menika wau anak kula ingkang mbajeng, lajeng menika puntepangaken mantu kula pun Nina. Nembe kemawon wangsul saking tugas belajar dhateng Jepang. (putra dan menantu Ibu Hami pada waktu itu sedang menyajikan makanan dan minuman dalam acara ngundhuh arisan)...".

"...ini tadi anak sulung saya terus ini kenalkan menantu saya Nina. Baru saja selesai tugas belajar dari Jepang...”.

Kemudian cucunya mendekat, dan oleh Eyang putrinya si cucu disuruh memberikan salam kepada teman-teman arisannya, dan si cucu pun dengan senyum mengikuti tuntunan eyangnya untuk bersalaman padsa para tamu. Dari perilaku dan sapaan ibu Hami tersebut dapat diketahui bahwa apa yang menurut beliau sikap baik kepada orang lain tetap dicontohkan kepada anak cucunya. Dengan demikian dapat dikatakan bahwa peran lansia dalam memberikan teladan kepada anak cucunya telah benar-benar dilaksanakan dengan baik. Menurut ibu Hami tindakan yang demikian sudah diterima sejak kecil dari orang tuanya, kemudian pada gilirannya diteruskan ditularkan atau diterapkan kepada anak cucunya.

Sikap keteladanan itu juga didukung oleh Bapak dan Ibu Karib dalam mewariskan nilai budaya dari pendahulunya, yakni dengan tetap memberikan keteladanan dalam berbagai aspek kehidupan. Menurut Bapak Ibu Karib keteladanan adalah suatu keharusan bagi beliau untuk mendidik anak-anaknya menjadi manu-sia yang berguna bagi nusa bangsa dan agama. Keteladan itu diterapkan dalam menjalankan sholat lima waktu. Keluarga tersebut selalu berusaha untuk menjalankan sholat subuh, magrib dan isya berjamaah, sedangkan dhuhur dan asar selalu menyesuaikan dengan kegiatan masing-masing.

Ibu Karib selalu menanamkan bahwa Bapak adalah seorang imam, dan seorang imam harus dihormati tanpa syarat. Mengenai hal ini Ibu Karib menuturkan seperti berikut.

"...ngormati bapak minangka imam iku hukume wajib Bu. Bocah-bocah pas ora kepeneran karo Bapake tetep wae ora kena terus arep sakepake karo Bapake, ora kena kaya ngono kuwi. Ning ya kuwi yen pas aku rada ora kepeneran karo Bapake ya kudu diempet ana ngarepe bocah-bocah. Nesonan karo Bapake ora kena suwesuwe, mesakke bocah-bocah entuk conto sing ora apik. Ning jane bocahbocah ya ngerti yen bapak-ibune lagi nesona. Biasane yen apik terus diolokolok 'baikan ni ye'...'. 
"...menghormati bapak sebagai imam itu hukumnya wajib Bu. Anakanak kalau pas agak jengkel sama Bapaknya tetap tidak boleh bersikap semaunya. Tetapi ya itu, kalau saya pas marahan sama Bapaknya juga harus menahan diri di depan anakanak. Marahan antara suami isteri tidak boleh lama-lama, kasihan anakanak mendapat perilaku yang kurang baik. Sebetulnya anak-anak tahu kalau kita pas marahan. Biasanya kalau sudah baikan, diledek oleh anak-anak 'baikan niye'...".

Keteladanan ini juga diperlihatkan oleh seorang lansia yang kira-kira berusia 80 tahun, ada salah satu cucunya baru menikahkan anaknya. Pada waktu itu lansia itu berdandan rapi memakai kebaya warna hitam bunga-bunga kecil putih dan kain panjang motif batik Yogyakarta, diwiru rapih, sambil duduk dikerubungi sanak saudara yang datang di tempat perhelatan tersebut. Pada pertemuan tersebut terjadi Perbincangan 1.

Dari percakapan ini dapat diketahui bahwa seorang lansia yang benarbenar lanjut usia memberikan tauladan penggunaan busana yang digunakan dalam perhelatan pernikahan dengan menggunakan busana tradisional kebaya dan kain panjang berwiru. Pada kesehariannya Mbah tersebut mengunakan kain-berkebaya tetapi tidak menggunakan wiru.

\section{Perbincangan 1}

Tamu: Sugeng Mbah? (alur keluarga kepernah cucu)

Mbah: Iya slamet piye kabare sasuwene ra ketemu, dha waras ta kabeh?

Tamu: Inggih pengestunipun sedaya sehat. Wah Simbah ki jan tetep kemawon lo, nyampingan wiron mboten kantun nggih Mbah?

Mbah: la iya ta ya, mengko nek Simbah neng nggon pengantenan ngagem ageman nglomprot anak putu dha isin, ra dha gelem ketemu simbah, wong nggon pengantenan ya kudu beda karo biasane ta, iya ra?

Tamu: Inggih Mbah leres, kagem nyontoni ingkang nem-nem menika lo Mbah!”

Tamu: apa kabar Mbah?

Mbah: iya baik, bagaimana kabarnya selama tidak ketemu, sehat semua?

Tamu: Iya Mbah berkat doa restu Mbah semua sehat. Wah Simbah itu tetap saja lo, pakai kain wiron tidak ketinggalan ya Mbah?

Mbah: iya, kalau Simbah di tempat pernikahan nggak pakai pakaian yang pantas, nglomprot, nanti anak cucu malu, tidak mau ketemu Simbah, di tempat pernikahan kok nglomprot. Di tempat hajatan pernikahan ya harus pakai pakaian yang berbeda dari biasanya, ya kan?

Tamu: iya Mbah betu, memberi contoh yang muda-muda ya Mbah?' 
Dalam inti percakapannya dapat diketahui isinya bahwa dalam berbusana seseorang harus sesuai dengan konteksnya. Berbusana menyesuaikan dengan konteksnya menurut Mbah untuk menjaga kehormatan. Kehormatan tersebut tidak hanya kehormatan untuk diri sendiri tetapi juga kehormatan anak cucu, serta untuk menghormati tamu atau orang lain.

Uraian di atas menujukkan bahwa keteladan dalam budaya Jawa memang diperlukan. Keteladanan ini juga dalam menanamkan sopan santun, lansia memberikan contoh bagaimana harus bersikap kepada tamu, kepada sesama, kepada yang lebih tua atau yang dituakan. Dalam budaya Jawa guru diberi jarwa dhosok digugu lan ditiru bukan wagu tur kuru atau wagu tur saru.

Menurut penuturan lansia tugas guru adalah mengajarkan sesuatu membimbing memberi contoh kepada anak cucu anggota keluarga lain dalam kelarga, masyarakat di lingkungannya yang nantinya diharapkan tersebar di dalam lingkungan yang lebih besa lagi. Berimbas kepada lingkungan yang lebih besar atau lebih luas karena individu adalah sekaligus sebagai makhkluk sosial merupakan anggota keluarga dan sekaligus anggota kelompok masyarakat yang lebih luas lagi.

Kehidupan lansia dalam kesehariannya yang meliputi lingkungan keluarga, lingkungan masyarakat, dan lingkungan pekerjaan atau profesi bagi yang masih aktif bekerja selain berperan sebagai teladan atau guru (baca bukan profesi) lansia menunjukkan adanya peran pengarah bagi anak cucu maupun generasi penerus di lingkungannya, seperti terlihat pada hasil Wawancara 1.

Para lansia dalam kehidupan sehari-hari juga menunjukkan peran yang sangat besar dalam memberikan semangat dalam segala hal kepada semua orang di sekelilingnya, khususnya kepada anggota keluarganya yaitu anak cucunya. Penyemangat ini kelihatan pada hasil wawancara yang didasarkan pada hasil penglihatan perilaku lansia dalam kehidupan kesehariannya, yakni pada waktu salah satu cucunya gagal mengikuti tes calon pegawai negeri di salah satu lembaga. Lansia itu dengan telatennya memberikan semangat kepada cucunya. Penjelasannya terlihat dalam hasil Wawancara 2.

Dalam hasil Wawancara 2 menunjukkan bahwa kedekatan Mbah uti dan cucunya dalam memberikan semangat untuk terus berjuang terkesan sambil berkelakar tidak seperti membicarakan hal yang serius. Hal memberikan semangat ini juga terlihat pada kegiatan konsultasi Ibu Hami kepada mahasiswa bimbingan tugas akhirnya yang agak tersendat-sendat tidak kunjung selesai. Peran penyemangat itu terlihat dalam Wawancara 3.

Pada hasil wawancara tersebut dapat dilihat bahwa lansia ber peran secara aktif dapat memberikan semangat kepada yang lebih muda, baik kepada anggota keluarganya - kepada cucu - dan sewaktu bertugas sebagai pembimbing kepada mahasiswa, dan ada perilaku lansia berkaitan dengan pemberian semangat ini kepada generasi penerusnya.

Peran lansia menjadi sahabat, teman diskusi ini kelihatan tetapi kurang masuk akal tetapi kenyataannya terjadi dalam kehidupan sehari-hari, baik di dalam keluarga, masyarakat di lingkungan tempat tinggal maupun di lingkungan tempat bekerja. Peran ini terlihat pada hasil wawancara dengan seorang Guru besar di lingkungan UNY yang disajikan pada Wawancara 4. 


\begin{tabular}{|c|c|}
\hline \multicolumn{2}{|r|}{ Wawancara 1} \\
\hline Peneliti & $\begin{array}{l}\text { Kadospundi Mbah kok Pak Sugi menika gesangipun setingal sekeca } \\
\text { ayem tentrem, putranipun sekolah sedaya, critanipun kados pundi? } \\
\text { Bapak Sugi kaliyan Bu Sakin rak namung PNS Iulusan SLA. }\end{array}$ \\
\hline Mbah Resa & $\begin{array}{l}\text { Wah critanipun panjang Nak. Rikala wiwitan mbangun kulawarga, } \\
\text { anak kula menika rak dereng sami nyambut damel lajeng kula ganani } \\
\text { sabin sekedhik, saking marasepuhipun ugi punparingi sabin kangge } \\
\text { gesang pedintenanipun. Senajan dereng nyambut damel cepet kula } \\
\text { emah-emahaken margi sekolahipun rak wonten Jakarta, mangke } \\
\text { mindak pados damelan wonten Jakarta lajeng mboten mantuk, mangke } \\
\text { ingkang nglajengaken gesang kula sinten? Untungipun boten dangu } \\
\text { lajeng sami saged nyambut damel, kangge gesang padintenanipun } \\
\text { saking bayaripun, asiling tetanen tetep dipuntampi. Ningali caranipun } \\
\text { ngecakaken asiling bayar lan tetanen kula tingali kok lajeng radi boros } \\
\text { boten purun ngengeh kangge kebetahan benjngipun. Sasampunipun } \\
\text { menika uger wancinipun badhe panen kula temtu ngusulaken "Nok si } \\
\text { Kemis kae arep ngedol pedhete, le nebaske kae dinggo nuku pedhete } \\
\text { Kemis wae, nggo ngengehan, piye" mantu kula kok ndilalah kok } \\
\text { nggih setuju. Lha sateruse ngaten, e kok dang dangu kula nggih saya } \\
\text { sepuh, mantu kula nggih saya ngandhang saben panenan temtu } \\
\text { puncanthelaken menapa ngaten. E alhamdulilah kok samenika anak- } \\
\text { anakipun kok saged dados sarjana, sampun sami nyambud damel. }\end{array}$ \\
\hline Peneliti & : Mbah kok putranipun nggih sami sarjana, dospundi critanipun? \\
\hline Mbah Resa & $\begin{array}{l}\text { Wah kula menika gesangipun rumiyin rekaos sanget, kula rumiyin } \\
\text { mande lurik wonten peken Beringarja. Saben enjing kinten-kinten } \\
\text { jam tiga enjing sampun bidhal mlampah dhateng peken, ngaten } \\
\text { bedintenipun. Lha wonten peken menika kula sumerep bakul gudheg, } \\
\text { saben enjing putra-putranipun nusul dhateng peken saderengipun } \\
\text { bidhal sekolah, putranipun gangsal, sami resik-resik penganggenipun. } \\
\text { E kula menika kok ngudaraos e mbok anak-anakku mbesuk nek } \\
\text { wis gedhe mbok dha bisa sekolah ben le golek rejeki ora susah kaya } \\
\text { mbokne. Lajeng saben laris dagangan kula temtu boten ketang sekedhik } \\
\text { kula temtu ngengeh, kula dlesepaken wonten ngandhap lempitan } \\
\text { rasukan. Lajeng gesang kula radi sekeca sasampunipun Bapakipun } \\
\text { rumiyin punajari numbasi pantun utawi asil tetanen sanesipun, kaliyan } \\
\text { priyantun sugih saking daeran caket Pakem. Pesenipun priyantun } \\
\text { menika dados tiyang menika pawitanipun jujur, tememen tur tliti } \\
\text { anggenipun nindakaken bebakulan. Lajeng sasampunipun mlampah } \\
\text { kula kendel bakul lurik, lajeng tetanen kaliyan nyambi numbas-numbasi } \\
\text { asiling tetanen, menawi wonten tirahan sekedhik-sekedhik kula celengi. }\end{array}$ \\
\hline
\end{tabular}




\section{Wawancara 2}

Peneliti : Mbah kok sajak wigatos sanget rembaganipun kaliyan Mbak Ning? Ning kok terus gegujengan wonten napa ta Mbah?

Mbah Resa : Oh menika ta. Putu kula menika rak mentas ndherek tes pegawai negeri, lha boten katut, kok terus ketingal suntrut. Putu-putu kula menika rak celak kalih mbahe niki. Dados nek wonten menapa-menapa terus crita. Menika namu ng kula sanjangi "...ora perlu susah nok wong ya lagi lulus wae kok. Sesuk kudu nyoba meneh". E malah wangsulane napa "Mbahuti aku ki ra susah, aku mikir-mikir sesuk nglamar nengdi meneh ya? Njih menika remenipun lajeng nggodhani mbahipun menika

\section{Wawancara 3}

Peneliti $\quad$ : Ibu ketingalipun mahasiswa menika kala wau kok radi dos pundi ngaten?

B Hami : Ah menika mahasiswa wah jaan angel sanget dudutanipun ngantos kula menika kadhang badhe nglokro. Ning gandheng pembimbing njih sakamat-kamat kedah dipunsurung terus. Saenipun lare menika manut, ngrumaosi menawi boten patos pinter. Mindhakipun namung sekedhik sekedhik sanget

\begin{tabular}{|c|c|}
\hline & Wawancara 4 \\
\hline Peneliti & : Ibu kok asyik sekali dengan tadi dosen mana ta $\mathrm{Bu}$ ? \\
\hline Prof St & $\begin{array}{l}\text { Ah biasa, kita baru ngobrol-ngobrol soal itu lo pengajuan proposal } \\
\text { penelitian. Mereka kan dosen baru belum pengalaman mengajukan } \\
\text { proposal. Ini tadi diskusi bagaimana cara mencari masalah yang } \\
\text { sekiranya menarik perhatian para penilainya. }\end{array}$ \\
\hline Peneliti & : Kok Ibu kelihatan akrab sekali? \\
\hline Prof St & $\begin{array}{l}\text { Oh iya harus begitu, jadi kita ini jadi orang tua harus mendekat kepada } \\
\text { mereka biar mereka nggak takut dan berani ngomong kalau ada apa- } \\
\text { apa. Di rumah juga begitu, anak-anak selalu saya biasakan untuk } \\
\text { crita masalah apapun, saya siap mendengarkan. Dan biasanya terus } \\
\text { kalau ada masalah baik akademis ataupun nonakademis dicari jalan } \\
\text { keluarnya. }\end{array}$ \\
\hline
\end{tabular}


Peran lansia sebagai sahabat, sebagai teman diskusi dapat juga terlihat dalam kehidupan seorang ibu dengan dua anaknya. Kehidupan sehari-harinya sebagai seorang ibu dengan dua anak, satu sudah bekerja dan yang satu masih kuliah di S2. Anak-anak itu lebih dekat kepada ibunya dibandingkan dengan ayahnya. Dalam kehidupan seharihari ibu tersebut untuk mengambil keputusan tidak pernah meninggalkan peran anaknya, baik dalam hal keuangan, rumah tangga maupun dalam hal berbusana. Peran tersebut terlihat dalam Wawancara 5.

Dari hasil wawancara tersebut menunjukkan bahwa para lansia dan kebanyakan yang sangat perperan adalah ibu, dapat menjadi sahabat, teman diskusi bagi yang lebih muda, baik di lingkungan

\begin{tabular}{|c|c|}
\hline \multicolumn{2}{|r|}{ Wawancara 5} \\
\hline Peneliti & $\begin{array}{l}\text { : Mbak kok anak-anak ketok cerak banget karo penjenengan nganti } \\
\text { saiki? }\end{array}$ \\
\hline B Karib & $\begin{array}{l}\text { Iya, takkulinakke kok wiwit isih cilik biyen. Bocah-bocah kuwi kudu } \\
\text { ngerti apa pegaweyane wong tuwane. Bapak-ibune gajine pira, } \\
\text { terus gaweyan saben dinane neng ngomah apa wae kudu resik- } \\
\text { resik, mangsak, ngumbahi, blanja apa wae }\end{array}$ \\
\hline Peneliti & : Terus piye mbak kok saiki kaya karo kancane wae? \\
\hline B Karib & $\begin{array}{l}\text { Ya kuwi mau takkulinakke wiwit cilik, yen ana apa-apa mesthi } \\
\text { takomongke karo dheweke ya karo bapake barang. Bapak ibu } \\
\text { bayare samene iki kudu cukup kanggo urip sesasi tambah kudu } \\
\text { nduwe celengan ra ketang sithik. Dadine dheweke ra wani nek } \\
\text { arep sakarepe dhewe nyuwun apa ta apa. Yen kepengen tenanan } \\
\text { dheweke matur kepengen apa wis duwe tabungan pira, terus lagi } \\
\text { nyuwun tambah. Nek gaweyan ngomah ya dum-duman sapa sing } \\
\text { nyapu, sapa sing ngumbahi, balanja, mangsak. Yen milih klambi } \\
\text { biasane ya omomng-omongan, cocok apa ora, terus sing mesthi } \\
\text { tambahi ana ora bu? Bareng wis dha kuliah kuliahe sing gedhe } \\
\text { na luar daerah, buku Taplusku rak digawa, sing cilik rak na kene } \\
\text { dadi gajine langsung. }\end{array}$ \\
\hline Peneliti & : Terus saiki piye Mbak bareng wis bisa golek dhuwit dhewe? \\
\hline B Karib & $\begin{array}{l}\text { Aku saiki dijatah karo anakku, saben sasi dikirimi dhuwit kanggo } \\
\text { amal, senajan ya ra akeh. Ning tetep wae yen biasane telpon saben } \\
\text { minggu ya ngobrol-ngobrol bab masalah gaweyan, terus karir ya } \\
\text { werna-werna }\end{array}$ \\
\hline
\end{tabular}


keluarga maupun di lingkungan tempat bekerja atau tempat tinggalnya.

\section{KESIMPULAN}

Penelitian tentang "Peran Lansia dalam Pewarisan Nilai-nilai Budaya" telah dilakukan dengan melakukan berbagai teknik untuk mendapatkan penjelasan tentang apa yang dilakukan oleh para lansia kaitannya dengan pewarisan nilai-nilai budaya di dalam lingkungannya, baik lingkungan keluarga maupun lengkungan tempat bekera dan lingkungan tempat tinggalnya. Dari uraian di atas dapat disimpulkan sebagai berikut.

Pertama, para lansia dalam kehidupan seharinya menjalani kehidupan ini dapat berperan sebagai teladan/ guru. Teladan di sini adalah kehidupan lansia baik tutur kata, perilaku dan berbusananya harus dapat dijadikan suri tauladan bagi anak cucunya ataupun bagi generasi mudanya. Kosa kata teladan dapat disamakan dengan guru, sebagai lansia segala perilakunya harus dapat dijadikan teladan atau panutan bagi anak cucu ataupun warga sekitarnya. Segala tutur katanya, perilaku dapat digugu lan ditiru oleh generasi penerusnya, baik anak cucu hubungan darah ataupun oleh anak cucu dalam artian yang luas, yakni anak cucu sebagai penerus bangsa.

Kedua, lansia berperan sebagai pengarah, penasehat, dan pengendali dalam kehidupan kesehariannya yang me-liputi lingkungan keluarga, lingkungan masyarakat, dan lingkungan pekerjaan atau profesi bagi yang masih aktif bekerja. Selain berperan sebagai teladan atau guru (baca bukan profesi) lansia menunjukkan adanya peran pengarah, penasehat, dan pengendali bagi anak cucu maupun generasi penerus di lingkungannya. Lansia sebagai orang yang berpengalaman dalam kehidupan telah banyak banyak asam garamnya, oleh karena iitu dapat memberikan pengarahan, pnasehat, dan pengendalian agar kehidupan generasi mudanya lebih baik.

Ketiga, lansia berperan sebagai penyemangat, secara aktif dapat memberikan semangat kepada yang lebih muda, baik kepada anggota keluarganya ada perilaku perilaku lansia betrkaitan dengan pemberian semangat ini kepada generasi penerusnya, baik dalam lingkungan keluarga, masyarakat lingkungan tempat tinggal dan masyarakat tempat pekerjaannya. Pemberian semangat juga doa merupakan peran lansia yang menonjol karena dilihat dari segi fisik lansia telah berkuran daya lentur, daya ingatnya terutama hal kekuatan fisiknya.

Keempat, peran lansia menjadi sahabat, teman diskusi ini kelihatan tetapi kurang masuk akal tetapi kenyataannya terjadi dalam kehidupan sehari-hari, baik di dalam keluarga, masyarakat di lingkungan tempat tinggal maupun di lingkungan tempat bekerja.

\section{DAFTAR PUSTAKA}

BPS DIY. 2002. Data Statistik Penduduk DIY. Yogyakarta: BPS DIY.

Koentjaraningrat. 1990. Kebudayaan Jawa. Yogyakarta: Gama University Press.

Miles, M.B., \& Huberman, A.M. 1994. Qualitative Data Analysis: An Expanded Sourcebook. California: Sage Publications.

Sedyawati, E. 2002. Penelitian Kualitatif Sosial-Keagamaan pada Pelatihan Metodologi Penelitian Bidang Sosial 
Keagamaan. Jakarta: DPPM Ditjen DIKTI.

Spradley, J.P. 1997. Metode Etnografi

(Terj.: Misbah Zulfa Elizabeth).

Yogyakarta: PT. Tiara Wacana Yogya.

Swasono, M.F.H. 1995. "Peranan dan

Kontribusi Usia Lanjut". Laporan
Penelitian. Fakultas Ilmu Sosial dan Ilmu Politik UI.

Undang-Undang Nomor 13 Tahun 1998 Tentang Kesejahteraan Lanjut Usia.

Williams, D.C. 1988. Naturalistic Inquiry Materials. Bandung: FPS IKIP. 